\title{
Kinetics of Respiration Reaction of Thiobacillus ferrooxidans with Several Iron(II) Complexes as Electron Donors
}

\author{
Hirosuke TATSUMI, Katsunori KaWAGUCHI, Kan Kato, Kenji Kano, \\ and Tokuji IKEDA*
}

Division of Applied Life Sciences, Graduate School of Agriculture, Kyoto University (Sakyo-ku, Kyoto 606-8502, Japan)

Received April 28, 2000 ; Accepted July 25, 2000

\begin{abstract}
Respiratory reaction of Thiobacillus ferrooxidans which uses $\mathrm{Fe}^{2+}$ as the substrate in acidic solution was analyzed by a Michaelis-Menten type equation, and the catalytic constant, $k_{\mathrm{B}, \mathrm{cat}}$, of the bacterial cell was determined as $3.0 \times 10^{6} \mathrm{~s}^{-1}$ for the first time. The Michaelis constant, $K_{\mathrm{m}, \mathrm{Fe}}^{\prime}$, for $\mathrm{Fe}^{2+}$ was determined to be $37 \mu \mathrm{M}$, which is much smaller than the values so far reported. In addition to $\mathrm{FeSO}_{4}$, a number of iron complexes $\left(\mathrm{Fe}(\mathrm{CN})_{6}{ }^{4-}\right.$, Fe-citrate, and ferrocene derivatives) functioned as the substrates in the respiration of $T$. ferrooxidans. The $k_{\mathrm{B}, \text { cat }}$ values with the iron complexes are in the same order of magnitude as that with $\mathrm{Fe}^{2+}, 0.71-3.0 \times 10^{6} \mathrm{~s}^{-1}$, while the $K_{\mathrm{m}, \mathrm{Fe}}$ values are widespread over the range from $1 \mu \mathrm{M}$ for $\mathrm{Fe}(\mathrm{CN})_{6}{ }^{4-}$ to $120 \mu \mathrm{M}$ for ferrocenecarboxaldehyde.
\end{abstract}

Key Words : Thiobacillus ferrooxidans, Iron Complexes, Respiration, Kinetic Analysis

\section{Introduction}

Thiobacillus ferrooxidans is a unique chemolithotrophic bacterium, which utilizes ferrous ion in sulfuric acid solution to obtain energy for supporting carbon dioxide fixation and growth. ${ }^{1}$ It is involved in the acid mine drainage, and has attracted considerable attention in applying to a process known as bacterial leaching. Since the cell yield is very low because of the culture on the energypoor inorganic substrate, attempts have been made to enhance the bacterial growth rate. There have been a considerable number of papers dealing with kinetics of the ferrous ion oxidation by $T$. ferrooxidans to seek an optimum condition for the bacterial growth. ${ }^{2-9)}$ Electrochemical regeneration of ferrous ion has been shown to provide a method for enhanced bacterial growth. ${ }^{10-14)}$ We have recently shown that $T$. ferrooxidans catalyzes the electrochemical reduction of $\mathrm{O}_{2}$ with hexacyanoferrate(II) as an electron transfer mediator between the bacterial cells and an electrode. ${ }^{15)}$ This indicates that hexacyanoferrate(II) can serve as a substrate for the bacterial respiration as ferrous ion does. Present paper deals with the determination of the catalytic constant and the Michaelis constant of the bacterial respiration reactions with several iron(II) complexes including ferrous ion and hexacyanoferrate(II). The constants provide a means of evaluating how effective the complexes are as the substrates of the bacterial cells.

\section{1 Bacterium and materials}

\section{Experimental}

Cultures of $T$. ferrooxidans were incubated in $500 \mathrm{~mL}$ Erlenmeyer flasks each containing $100 \mathrm{~mL}$ of $9 \mathrm{~K}$ medium ${ }^{16)}$ and $3 \mathrm{~mL}$ inoculum at $28^{\circ} \mathrm{C}$ on a rotary shaker at $200 \mathrm{rpm}$. Cells were harvested toward the end of their exponential phase of growth. In order to remove the in- soluble ferric ion compounds, the cultures were filtered through a Toyo No. 2 filter paper. The filtrate was then centrifuged at $10000 \times \mathrm{g}$ for $15 \mathrm{~min}$. The cells were washed twice with $10 \mathrm{mM} \mathrm{H}_{2} \mathrm{SO}_{4}$ and suspended in a sulfuric acid solution of $\mathrm{pH}$ 3.0. The activity of the bacterial cells for the oxidation of ferrous ion remained unchanged at least for a month when the suspension was stored at $5{ }^{\circ} \mathrm{C}$. The bacterial concentration in the suspension was determined by measuring absorbance at 610 $\mathrm{nm}$. The cell number contained in the suspension of unit absorbance was calculated to be $9.6 \times 10^{8}$ cells per $\mathrm{cm}^{3}$, or $1.6 \times 10^{-12} \mathrm{~mol} \mathrm{dm}^{-3}(\mathrm{M})$ by using a hemacytometer.

Ferrous citrate (Fe(II)-citrate) was prepared by the addition of $\mathrm{FeSO}_{4}$ into a solution containing excess amount of citrate. Ferrocenecarboxylic acid $(\mathrm{Fc}-\mathrm{COOH})$ and ferrocenecarboxaldehyde $\left(\mathrm{Fc}-\mathrm{CO}_{2} \mathrm{CHO}\right)$ were purchased from Aldrich $\mathrm{Co}$., and ferrocenylethanol $(\mathrm{Fc}-\mathrm{EtOH})$ was from TCI Co. All other chemicals used were of reagent grade and were used as received.

\section{2 Measurement of the respiration activity of $T$.} ferrooxidans

The concentrations of iron complexes in the bacterial suspension were measured by an electrochemical method using a film-coated electrode as described previously. ${ }^{17}$ Polycarbonate membrane $(10 \mu \mathrm{m}$ thick, pore size $0.4 \mu \mathrm{m}$, Advantec Co.) and a glassy carbon electrode (3.0 mm i.d., No 11-2012, BAS Inc.) were used in preparing the film-coated electrode. A current-time curve was recorded at a fixed potential in an air-saturated stirred

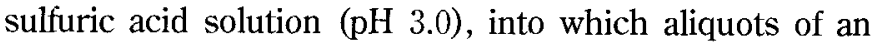
iron complex stock solution and the cell suspension were injected successively. In case of Fe(II)-citrate complex, a $\mathrm{pH} 3.0$ citric acid solution was used instead of the sulfuric acid solution. Sedimentation of the bacterial cells in the test solution was not observed during the course of 
the electrochemical measurements. The measurements were conducted with a BAS CV-50W voltammetric analyzer in a one-compartment electrolysis cell with a sample volume of $1 \mathrm{~mL}$. A platinum disk, and an $\mathrm{Ag}|\mathrm{AgCl}|$ sat. $\mathrm{KCl}$ electrode were used as the auxiliary, and reference electrodes, respectively. All measurements were carried out at $25^{\circ} \mathrm{C}$.

The concentration of dissolved $\mathrm{O}_{2}$ in a $T$. ferrooxidans cell suspension was measured by means of a Clark-type electrode assembly (Oxygraph type 8, Central Science Co.).

\section{Results and Discussion}

3. 1 Stoichiometry for the ferrous ion and hexacyanoferrate(II) oxidation through the respiration of $T$. ferrooxidans

It is known that $T$. ferrooxidans possesses a terminal oxidase, ${ }^{1)}$ which reduces $\mathrm{O}_{2}$ to produce 2 molecules of $\mathrm{H}_{2} \mathrm{O}$ during the respiratory reaction. Thus over-all respiratory reaction scheme of $T$. ferrooxidans with ferrous ion as substrate is:

$$
4 \mathrm{Fe}^{2+}+4 \mathrm{H}^{+}+\mathrm{O}_{2} \stackrel{\text { T. ferrooxidans cells }}{\longrightarrow} 4 \mathrm{Fe}^{3+}+2 \mathrm{H}_{2} \mathrm{O}
$$

Figure $1 \mathrm{~A}$ shows that the current of an oxygen electrode immersed in a solution containing $0.50 \mathrm{mM} \mathrm{Fe}{ }^{2+}$ starts to decrease by the addition of $T$. ferrooxidans cells and approaches about half the magnitude of the initial current. Considering that an air-saturated solution contains $0.25 \mathrm{mM} \mathrm{O}_{2}$ at $25^{\circ} \mathrm{C}^{18)}$ we can say that 0.12 to 0.13 $\mathrm{mM} \mathrm{O} \mathrm{O}_{2}$ was consumed by the bacterial respiration with $0.50 \mathrm{mM} \mathrm{Fe} \mathrm{F}^{2+}$. This confirms eq. (1) as the respiration reaction of $T$. ferrooxidans. Similar current decrease was also observed when the bacterial suspension contained $0.50 \mathrm{mM} \mathrm{Fe}(\mathrm{CN})_{6}{ }^{4-}$ instead of $\mathrm{Fe}^{2+}$ (Fig. $1 \mathrm{~B}$ ), revealing that not only $\mathrm{Fe}^{2+}$ but also $\mathrm{Fe}(\mathrm{CN})_{6}{ }^{4-}$ serves as a substrate for the respiration of $T$. ferrooxidans.

Difference in the slope between curves A and B (Fig. 1) reflects the difference in the bacterial respiration rate with $\mathrm{Fe}^{2+}$ and $\mathrm{Fe}(\mathrm{CN})_{6}{ }^{4-}$ as the substrate. The respiration rate should depend on the concentrations of the bac-

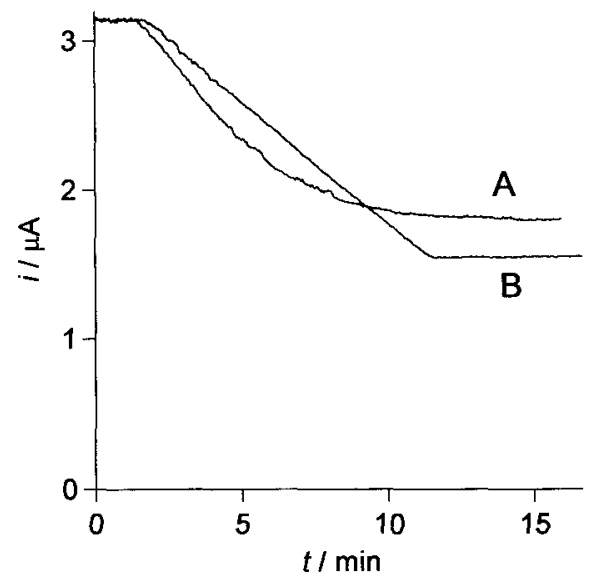

Fig. $1 \mathrm{O}_{2}$ consumption by T. ferrooxidans with (A) $0.50 \mathrm{mM}$ $\mathrm{FeSO}_{4}$ and (B) $0.50 \mathrm{mM} \mathrm{K}\left[\mathrm{Fe}(\mathrm{CN})_{6}\right]$ as substrates. T. ferrooxidans cells: (A) $1.6 \times 10^{-13} \mathrm{M}$, (B) $2.2 \times 10^{-13} \mathrm{M}$. terial cells and the substrate as well as the catalytic constant and Michaelis constant for the substrate as described below. The linear current decrease up to the inflection point (curve $\mathrm{B}$ ) indicates that the value of the Michaelis constant for $\mathrm{Fe}(\mathrm{CN})_{6}{ }^{4-}$ is very small (see below and Table 1).

3. 2 Kinetics of the oxidation of iron(II) complexes by the respiration of $\boldsymbol{T}$. ferrooxidans

The oxidation of $\mathrm{Fe}^{2+}$ by $T$. ferrooxidans cells is easily measured by the electrochemical method as depicted in Fig. 2. The current measured at $1.0 \mathrm{~V}$ in a pH 3.0 sulfuric acid solution started to appear by the addition of 1.5 $\mathrm{mM} \mathrm{FeSO}_{4}$ (arrow A) and attained a steady state, whose magnitude is proportional to the concentration of $\mathrm{Fe}^{2+}$. When $9.6 \times 10^{-13} \mathrm{M}$ of $T$. ferrooxidans cells were added (arrow B), the current begins to decrease because of the bacterial respiration. The initial rate, $v_{0}$, of the $\mathrm{Fe}^{2+}$ consumption can be calculated from the initial slope of the current decrease. As shown in Fig. 3, vo is proportional to the concentration of the bacterial cell, $[\mathrm{B}]$. Dependence of $v_{0}$ on the concentration of $\mathrm{Fe}^{2+},[\mathrm{Fe}]$, is illustrated in Fig. 4, which shows a saturation tendency inherent in the enzyme kinetics. Thus, the dependence of

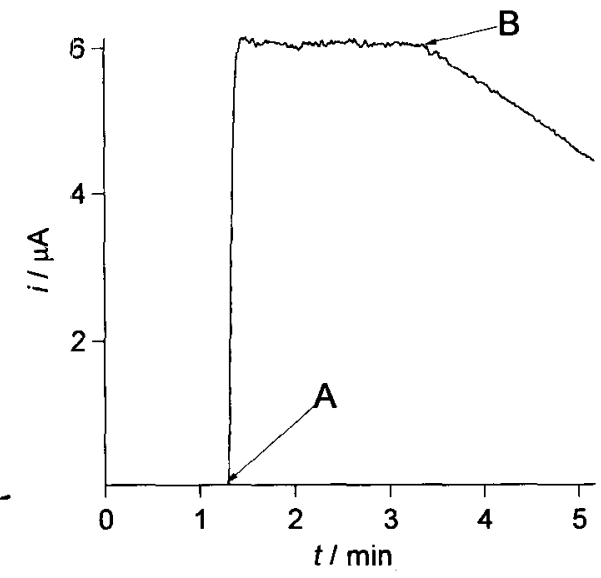

Fig. 2 A current-time $(i-t)$ curve measured with a membranecoated electrode at $1.0 \mathrm{~V}$. A: $\mathrm{FeSO}_{4}$ and $\mathrm{B}:$ T. ferrooxidans cells were successively added to make the final concentrations $1.5 \mathrm{mM}$ and $9.6 \times 10^{-13} \mathrm{M}$.

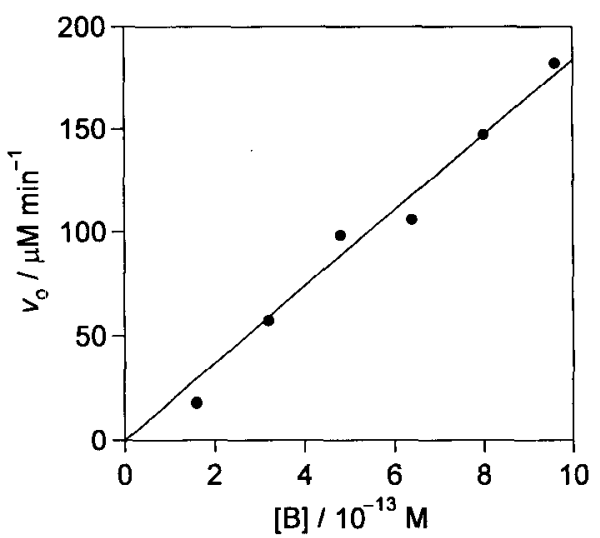

Fig. 3 Plots of $v_{0}$ vs. the concentration of $T$. ferrooxidans cells. $\mathrm{FeSO}_{4}: 1.5 \mathrm{mM}$. 
Table 1 Kinetic parameters for Fe(II) oxidation by Thiobacillus ferrooxidans cells.

\begin{tabular}{ccccccc}
\hline Substrate & $\mathrm{FeSO}_{4}$ & $\mathrm{~K}_{4}\left[\mathrm{Fe}(\mathrm{CN})_{6}\right]$ & $\mathrm{Fe}(\mathrm{II})$-citrate & $\mathrm{Fc}-\mathrm{COOH}$ & $\mathrm{Fc} \mathrm{CO}_{2} \mathrm{CHO}$ & $\mathrm{Fc}-\mathrm{EtOH}$ \\
\hline$k_{\mathrm{B}, \mathrm{cat}} / \mathrm{s}^{-1}$ & $3.0 \times 10^{6}$ & $1.5 \times 10^{6}$ & $7.1 \times 10^{5}$ & $2.6 \times 10^{6}$ & $1.6 \times 10^{6}$ & $1.1 \times 10^{6}$ \\
$K^{\prime}{ }_{\mathrm{m}, \mathrm{Fe}} / \mu \mathrm{M}$ & 37 & 1 & 7.7 & 51 & 120 & 20 \\
\hline
\end{tabular}

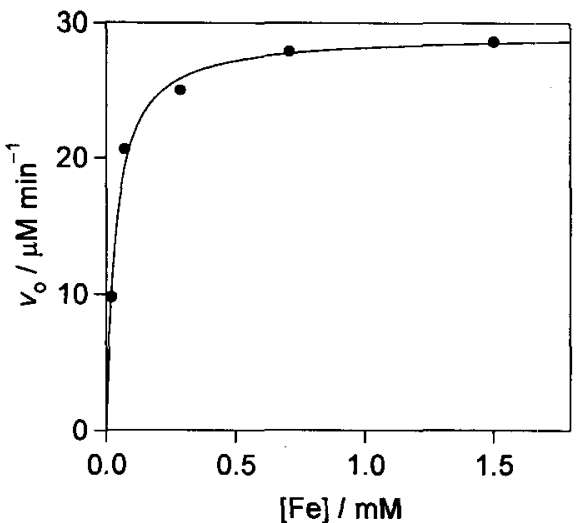

Fig. 4 Dependence of $v_{0}$ on the concentration of $\mathrm{FeSO}_{4} . T$. ferrooxidans: $1.6 \times 10^{-13} \mathrm{M}$.

$v_{0}$ on the concentrations of the bacterial cell and $\mathrm{Fe}^{2+}$ can be expressed by a Michaelis-Menten type equation written by

$$
v_{0}=k_{\mathrm{B}, \mathrm{cat}}[\mathrm{B}][\mathrm{Fe}] /\left(K_{\mathrm{m}, \mathrm{Fe}}^{\prime}+[\mathrm{Fe}]\right)
$$

where $k_{\mathrm{B}, \text { cat }}$ is the catalytic constant for a $T$. ferrooxidans cell and $K_{\mathrm{m}, \mathrm{Fe}}^{\prime}$ the apparent Michaelis constant for the iron compound. The values of $k_{\mathrm{B}, \text { at at }}$ and $K_{\mathrm{m}, \mathrm{Fe}}^{\prime}$ obtained by nonlinear regression of the experimental data by eq. (2) are given in Table 1 . When $\mathrm{Fe}(\mathrm{CN})_{6}{ }^{4-}$, Fe-citrate, Fc$\mathrm{COOH}, \mathrm{Fc}-\mathrm{CH}_{2} \mathrm{CHO}$, and Fc-EtOH are used as the substrate, similar behavior to that for $\mathrm{FeSO}_{4}$ was observed and the results were analyzed by eq. (2). Table 1 summarizes the $k_{\mathrm{B}, \mathrm{cat}}$ and $K_{\mathrm{m}, \mathrm{Fe}}^{\prime}$ values for these iron complexes. Interestingly, the $k_{\mathrm{B}, \text { cat }}$ values are in the same order of magnitude for all the iron complexes examined, $0.71-3.0 \times 10^{6} \mathrm{~s}^{-1}$. On the other hand, the $K_{\mathrm{m}, \mathrm{Fe}}^{\prime}$ values are widespread over the range from 1 to $120 \mu \mathrm{M}$. The $K_{\text {m,Fe }}^{\prime}$ value for $\mathrm{FeSO}_{4}, 37 \mu \mathrm{M}$, is much smaller than those reported by many workers. ${ }^{2-7,13)}$ The reason for the large discrepancy between our $K_{\mathrm{m}, \mathrm{Fe}}^{\prime}$ value and those by others is not clear. However, we may say that the spectrophotometric method ${ }^{2,4,7)}$ or oxygen electrode method $^{3,5,6,13)}$ employed previously are not appropriate for the measurements of $\mathrm{Fe}^{2+}$ concentrations as low as $30 \mu \mathrm{M}$. Our method as exemplified in Fig. 2 can measure the concentrations of iron complexes down to less than 1 $\mu \mathrm{M}$.

This is the first report for the measurement of the $k_{\mathrm{B}, \mathrm{cat}}$ values, which express the respiration rates of $T$. ferrooxidans cell with the iron complexes as the substrates. We have shown that a number of bacterial species, Gluconobacter industrius, Pseudomonas fuorescens, and Acetobacter aceti give $k_{\mathrm{B}, \text { cat }}$ values comparable to those in Table 1 with organic compounds, glucose and ethanol, as the substrates. ${ }^{19)}$ Thus, we may say that the respiration reac- tion of $T$. ferrooxidans using the iron complexes as the substrate is as fast as the ordinary bacterial respirations using organic substrates.

The oxygen consumption rates in the respiration reaction were measured under the same experimental conditions as above (Fig. 2) with an oxygen electrode. The current at the oxygen electrode decreased linearly by the addition of the bacterial cells to the solution until the current reached one tenth of the initial current magnitude, which corresponds to the $\mathrm{O}_{2}$ concentration, $\left[\mathrm{O}_{2}\right]$, of about $25 \mu \mathrm{M}$. This fact indicates that the bacterial respiration rate is independent of the $\mathrm{O}_{2}$ concentration at least at $\left[\mathrm{O}_{2}\right]>25 \mu \mathrm{M}$ and accordingly that the apparent Michaelis constant for $\mathrm{O}_{2}, K_{\mathrm{m}, \mathrm{o}}^{\prime}$, has a value smaller than $25 \mu \mathrm{M}$. This assures that the respiration rate of $T$. ferrooxidans is not limited by the concentration of $\mathrm{O}_{2}$ under air-saturated conditions $(0.25 \mathrm{mM})$.

\section{Acknowledgments}

This research was supported in part by a grant from Kansai Research Foundation for technology promotion. T. I. expresses his thanks to Professor Tsuyoshi Sugio, Okayama University for a kind gift of a stain of $T$. ferrooxidans.

\section{References}

1) W. J. Ingredew, Biochim. Biophys. Acta, 683, 89 (1982).

2) C. A. Schnaitman, M. S. Korczynski, and D. G. Lundgren, J. Bacteriol., 99, 552 (1969).

3) C. Bodo and D. G. Lundgren, Can. J. Microbiol., 20, 1647 (1974).

4) M. Steiner and N. Lazaroff, Appl. Microbiol., 28, 872 (1974).

5) A. A. DiSpirito and O. H. Tuovinen, Arch. Microbiol ., 133, 33 (1982).

6) I. Suzuki, H. M. Lizana, and P. D. Tackaberry, Appl. Environ. Microbiol., 55, 1117 (1989).

7) K. Nyavor, N. O. Egiebor, and P. M. Fedrak, Appl. Microbiol. Biotechnol., 45, 688 (1996).

8) S. Nagpal, Biotechnol. Bioeng., 53, 310, (1997).

9) F. K. Crundwell, Bioelectrochem. Bioenerg., 43, 115 (1997).

10) N. A. Kinsel and W. W. Umbreit, J. Bacteriol., 87, 1243 (1964).

11) S. B. Yunker and J. M. Radovich, Biotech. Bioeng., 28, 1867 (1986).

12) M. Taya, H. Shiraishi, T. Katsunishi, and S. Tone, $J$. Chem. Eng., 24, 291, (1991).

13) R. C. Blake II, G. T. Howard, and S. McGinness, Appl. Environ. Microbiol., 60, 2704 (1994).

14) S. Nakasono, N. Matsumoto, and H. Saiki, Bioelectrochem. Bioenerg., 43, 61 (1997).

15) T. Ikeda, K. Takagi, H. Tatsumi, and K. Kano, Chem. Lett., 1997, 5.

16) M. P. Silverman and D. G. Lundgren, J. Bacteriol., 77, 
642 (1959).

17) T. Ikeda, T. Kurosaki, K. Takayama, K. Kano, and K. Miki, Anal. Chem., 68, 192 (1996).

18) Kagaku Binran (Ed. Chemical Society of Japan), Maruzen, Tokyo, p.II-158, (1984) (in Japanese).
19) T. Ikeda, K. Kano, and K. Kato, New Directions in Electroanalytical Chemistry (Eds. J. Leddy and R. M. Wightman), PV 96-9, p.274, The Electrochemical Society Proceedings Series, Pennington, NJ (1996). 